\title{
EFFECTIVENESS OF PROTECTIVE POTENTIALS OF CHICKEN EGG YOLK IN CONTROLLING SALMONELLOSIS USING LABORATORY MICE AS A MODEL
}

\author{
ROFAIIL, S.K. and GERMIN S.SAAD
}

Veterinary serum and vaccine Research institute, ARC, Dokki, Giza

(Manuscript received 16 January 2013)

\begin{abstract}
This work has been designed to investigate the protective potential of chicken egg yolk against salmonella infection using laboratory mice as a model. Mice that treated by egg yolk and experimentally infected with salmonella typhimurium showed survival rate of $92 \%$ and absence of infected bacteria compared to non treated group (20\%). Histopathological examination revealed that treated group showed complete absence of histopathological changes in intestine and only few histopathological changes in liver and heart, while non treated group showed mucosal goblet cells formation with lymphoid follicular hyperplasia in serosa of intestine, significant infiltration of liver with leucocytic cells in hepatic tissue with necrotic changes and the heart showed leucocytic inflammatory cells infiltration in Between Bundles of degenerated cardiac muscles.

So chicken egg yolk can be used in enhancing the immune system and could be effective in protecting different animal species against salmonella infection.
\end{abstract}

\section{INTRODUCTION}

Salmonellosis remain one of the most important causes of death in animal species and act as a major disease problem facing live stock production that lead to great economic losses, in which the immune deficiency status play an important role in the progress of the Bacteria (Pietro and dun can 2006).

Treatment of salmonellosis in animals is often ineffective due to the presence of antibiotic drug resistant strain of salmonella and failure to identify the drug susceptibility pattern of involved strain (Quinn et al, 2002). Many other drugs and chemicals that can enhance various aspects of the immune response, (immunopotentiation) had been tested to increase the rate at which the immune response develop against such infection (Rofaiil, and Dooud 2005, and Rofaiil, 2007). Furthere more the possibility of preventing the diseases using Natural and/or herbal medicine attracted considerable attension. (Rofaiil et al, 2011).

During the last years great attention has been directed to the use of natural therapeutic agents against many infection, of which yolk of vaccinated chicken have been used for prophyloxis and treatment so used for prevention and control of 
infection through passive immunity (Ikemori et al, 1997). As little effort has been done on investigation the role played by egg yolk to enhance the therapeutic effect for controlling some infection. So this study aimed to determine the protective effect of chicken egg yolk in controlling salmonellosis in mice as an animal model by administration of chicken egg yolk from vaccinated hens followed by experimental infection by salmonella typhimurium organisms.

\section{MATERIALS AND METHODS}

\section{Experimental Hens :}

A total Number of 30 laying hens of about five months old age were used for egg yolk production.

\section{Experimental Mice :}

One Hundred and fifty healthy mice of 10 days old were kept in separated cages under strict hygienic condition during the experiment.

\section{Vaccine :}

Imported inactivated Bivalent vaccine of salmonella typhimurium and salmonella enteritidis was used in vaccination of chicken.

\section{Salmonella typhimurium strain :}

Local isolate of salmonella typhimurium used in challenge test was identified through gram staining, colonial morphology, biochemical and serological reaction by using standard +ve reference serum against salmonella typhimurium as described by (Forbes et al., 1998).

\section{Vaccination of hens :}

Hens were divided into 2 group (15 each) the first group was vaccinated by inactivated Bivalent vaccine of salmonella with $1 \mathrm{ml}$ dose $\mathrm{I} / \mathrm{M}$. to obtain the immune egg yolk, vaccination was done according to method described by (Ikemori et al, 1997) and (Germin 2007). The second group was kept non vaccinated control group.

\section{Egg yolk samples :}

Egg yolk were collected weekly after vaccination for a period 2 Month separated, then collected in clean dry screwe copped bottles and preserved till use as method described by (Svendsen et al., 1995).

Also egg yolk were collected from non vaccinated chickens as previously mentioned. 
To determine the effective immunized egg yolk by measured the level of antibodies in sera of vaccinated chickens as method described by (Ikemori et al 1997)

\section{Experimental designs :}

Experimental mice with age of 10 day, were divided into 3 groups (50 mice each) as follow :

Group (1): Mice were administrated orally $0.5 \mathrm{ml}$ egg yolk form vaccinated chicken daily for a period 10 days, then this group experimentally infected intra peritoneally with $0.5 \mathrm{ml}$ of twenty four hours broth culture of salmonella Typhimurium containing $1.5 \times 10^{8} \mathrm{CFU} / \mathrm{ml}$. such mice were abserved daily after experimental infection and mortalities were recorded.

Group (2): Mice were admistrated $0.5 \mathrm{ml}$ orly egg yolk from non vaccinated chicken and this group follow the same scheme as mentioned in group (1).

Group (3) : control group not administrated egg yolk and not experimentally infected with salmonella typhimurium.

Smears from internal organs of freshly dead mice were subjected to bacterialogical examination for reisolation of the organism.

Reisolation of the organism was done as described by Forbes et al, (1998). For histopathological examination tissue samples from the intestine, liver and heart of dead mice post experimental infection were collected and fixed in $10 \%$ formalin, washed by tap water, dehydrated in graded ethanol, embedded in paraffin sectioned at $4-5$ Microns and stained by hematoxylin and eosin following the standard technique of (Bancroft et al, 1994).

\section{RESULTS AND DISCUSSION}

This work has been designed to determine the protective potential of vaccinated chicken egg yolk against salmonella infection.

Data presented in table (1) showed that the globulin mean valves were gradually elevated in serum post vaccination in comparison to control group and reached the maximum titre at 7 weeks post vaccination.

Data recorded in table (2) showed that mice received immunized egg yolk resist infection with salmonella typhimurium and the percentage of their survival rate reached to $92 \%$ compared to $20 \%$ of the second group. 
From the obtained results the anti microbial immune response produced by treated mice with immunized egg yolk is similar to that obtain by Kuroki et al, (1993) who found that egg yolk immunoglobulin protect mice against experimental infection by Rota virus. Also Hiraga et al, (1990) reported that egg yolk derived from immunized hens is though to provide a significant efficient source of antibodies and can prevent Rota virus infection.

Egg yolk antibodies resulted from vaccination of laying hens are thought to provide a suitable source of immunity to mice against experimental infection by salmonella typhimurium. This results are similar to that abtained by Ikemori et al, (1992) who proved that oral administration of the egg yolk to calves could save as an important mode of treatment against colibacillosis in those exposed to enterotoxigenic strain.

The strong effectiveness of egg yolk antibodies to infectious pathogen also reported by yokoyama et al, (1992). Who added that addition of egg yolk to the feed or formula or even application as a separate therapeutic agent for Neonatal piglets.

Reisalation of bacteria in treated group revealed abscence of salmonella typhimurium in internal organs, blood samples and even the shedding in the faeces. Mean while the clear detection of salmonella typhimurium in internal organs, blood samples and still shedding in the faeces in the other group. Those finding were similar to that described by Percy and barthold (2001).

From the pathological point of view the group of mice treated with immunized egg yolk and experimentally infected by salmonella typhimurium showed that the intestine can resist the intra peritoneal inoculation with salmonella typhimurium, they appeared nearly normal macroscopically and microscopically, but the liver showed few focal area of fatty changes in the hepatocytes, and the heart showed few histopathological changes as focal haemorrhage in between myocardial bundles.

These results are in complete agreement with those of Sugita et al, (2002) who found that experimental infection with salmonella in BALB/C Mice and oral administration of an egg yolk derivatives can prevent the Bacteria from proliferation in internal organs.

In group of Mice treated with non immunized egg yolk and experimentally infected by salmonella typhimurium, the intestine showed mucosal goblet cells formation with lymphoid follicular hyperplasia in serosa. The liver showing leucocytic cells infiltration in between hepatic tissue and hepatocellular necrosis, and the heart showed hyperemic myocardial blood vessels and leucocytic cells infiltration in between the degenerated myocardial bundles. Those finding were similar to those described by Percy and barthold (2001). 
The control group did not show any pathological changes in intestine or liver and heart .

From the obtained results it could be concluded that the effectiveness of egg yolk antibody can favor a source as alternative protective potential or adjacent therapeutic with treatment in emergencies as it is reported that it can be used for passive protection against salmonellosis in animals.

Table 1. Mean values of the total globulins in sera of different groups of hens estimated by zinc sulphate turbidity test.

\begin{tabular}{|c|c|c|}
\hline \multirow{2}{*}{ Time of vaccination /week } & \multicolumn{2}{|c|}{ Total globulins concentration (gm\%) } \\
\cline { 2 - 3 } & Vaccinated group & Control group \\
\hline 0 & 2.57 & 2.50 \\
\hline $1 \mathrm{w}$ & 3.10 & 2.80 \\
\hline $2 \mathrm{w}$ & 3.20 & 2.95 \\
\hline $3 \mathrm{w}$ & 3.30 & 3.15 \\
\hline $4 \mathrm{w}$ & 3.36 & 3.30 \\
\hline $5 \mathrm{w}$ & 3.39 & 3.31 \\
\hline $6 \mathrm{w}$ & 3.80 & 3.00 \\
\hline $7 \mathrm{w}$ & 3.90 & 3.01 \\
\hline $8 \mathrm{w}$ & 3.90 & 3.01 \\
\hline
\end{tabular}

Table 2. Efficiency of immunized egg yolk administration on mice experimentally infected with salmonella typhimurium .

\begin{tabular}{|c|c|c|l|l|}
\hline \multirow{2}{*}{$\begin{array}{c}\text { Group of } \\
\text { Mice }\end{array}$} & $\begin{array}{c}\text { No. of dead } \\
\text { Mice/total No. of } \\
\text { Mice }\end{array}$ & $\begin{array}{c}\text { Mortality } \\
\text { Rate }\end{array}$ & $\begin{array}{l}\text { No. of } \\
\text { survived }\end{array}$ & Mice \\
Total & Protection \% \\
\hline Group (1) & $4 / 50$ & $8 \%$ & $46 / 50$ & 92 \\
\hline Group (2) & $40 / 50$ & $80 \%$ & $10 / 50$ & 20 \\
\hline Group (3) & $0 / 50$ & $0 \%$ & $50 / 50$ & 100 \\
\hline
\end{tabular}

Group (1) : administrated immunized egg yolk and infected with salmonella typhimurium.

Group (2) : : Administrated non immunized egg yolk and infected with salmonella typhimurium

Group (3) : control not administrated egg yolk and not infected with salmonella typhimiurim. 


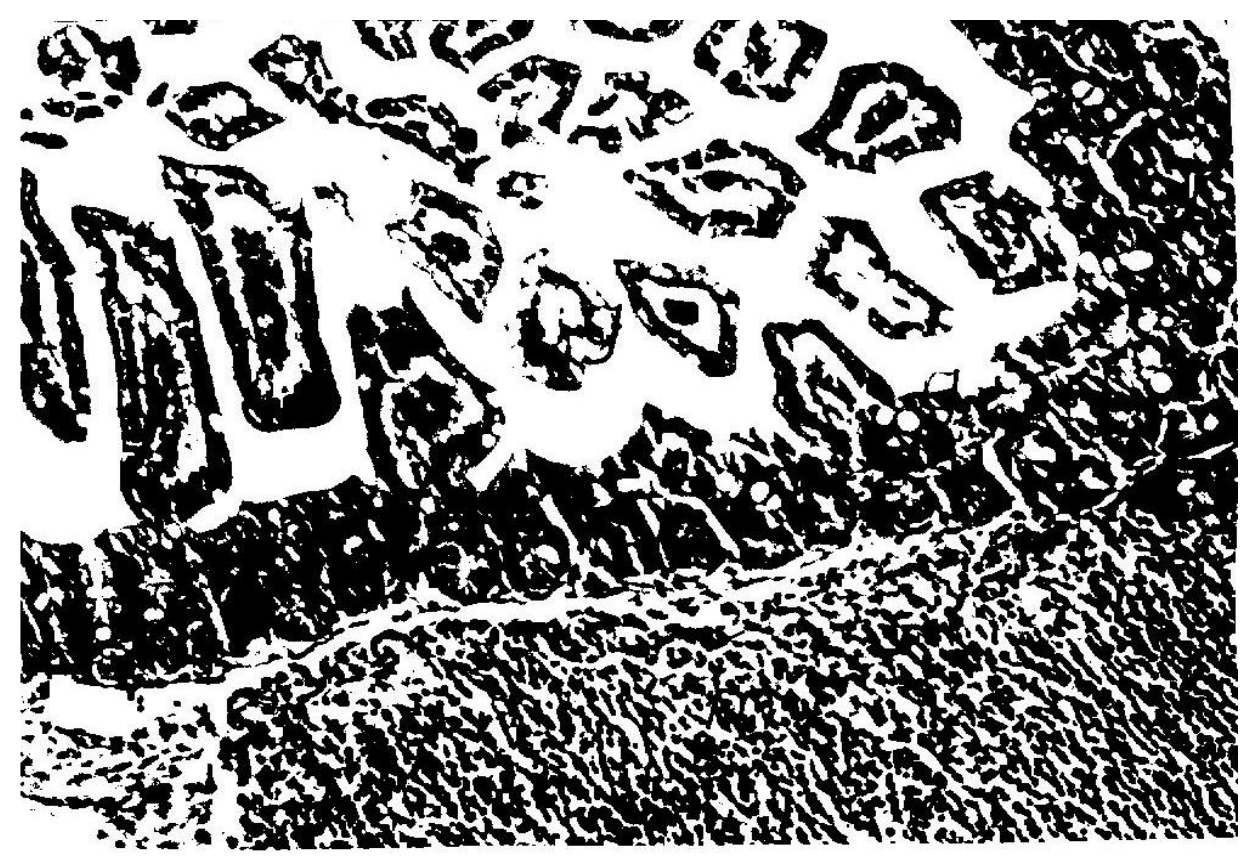

Fig 1. intestine of mice that administrated non immunized egg yolk and inoculated (I/P) by salmonella typhimurium showing mucosal goblet cells formation ( $\mathrm{g}$ ) with lymphoid follicular hyperplasia in serosa.

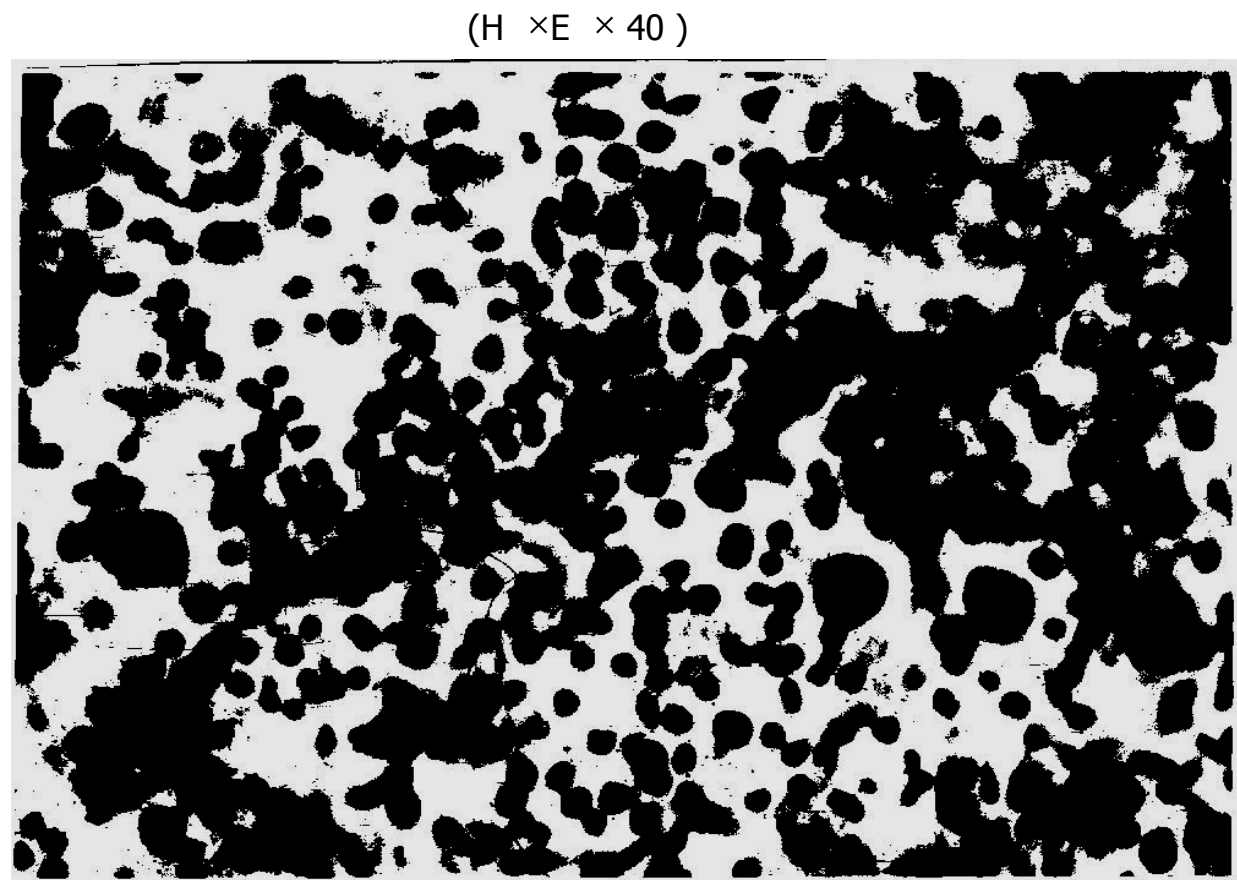

Fig 2. liver of mice that administrated non immunized egg yolk and inoculated (I/p) by salmonella typhimirim showing leucocytic cells infilteration in Between Hepatic tissue and hepatocellular necrosis.

$(\mathrm{H} \times \mathrm{E} \times 40)$ 


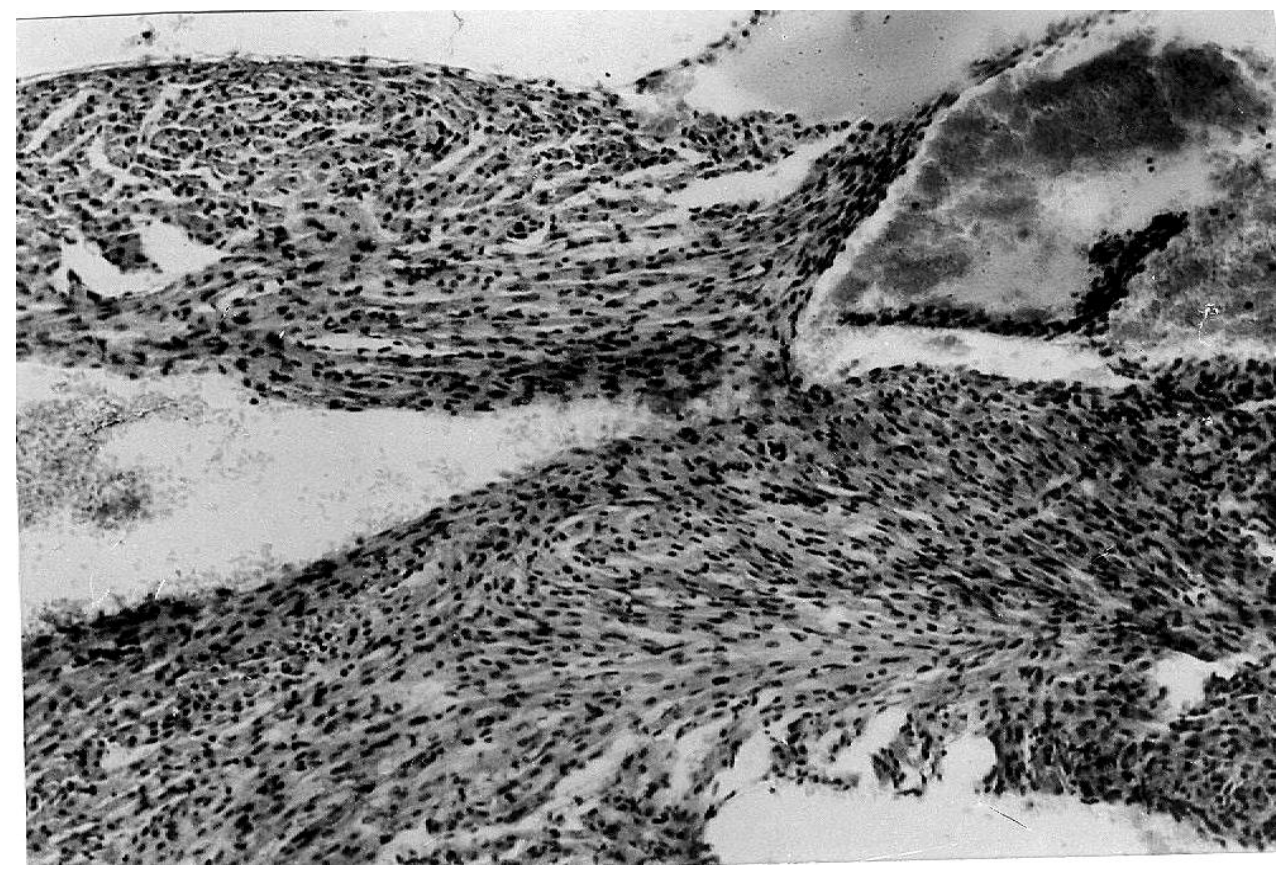

Fig 3. Heart of mice that administrated non immunized egg yolk and inoculated (I/p) by salmonella typhimurium showing hyperemic myocardial blood vessels and leucocytic cells infilteration in between the degenerated myocardial bundle.

( $\mathrm{H} \times \mathrm{E} \times 40$ )

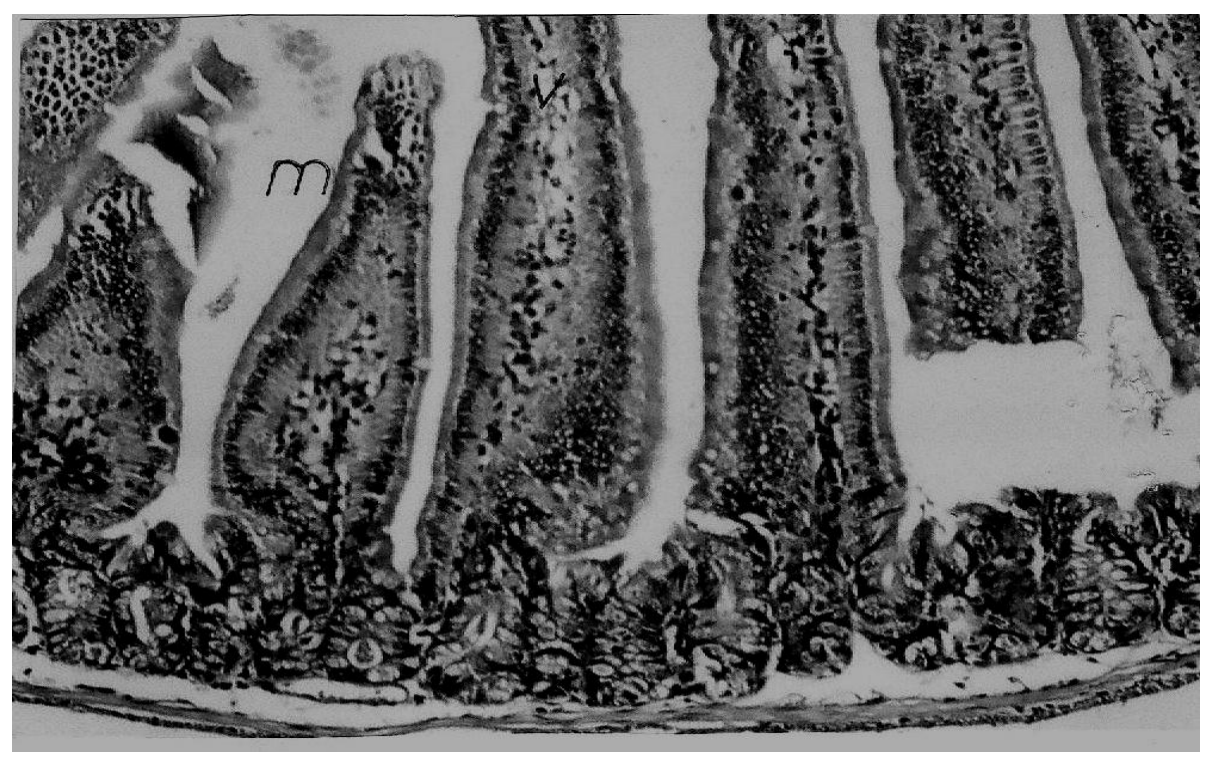

Fig 4. intestine of Mice administrated immunized egg yolk and inoculated (I/p) by salmonella typhimurim showing intact normal histological structure.

$(\mathrm{H} \times \mathrm{E} \times 40)$ 


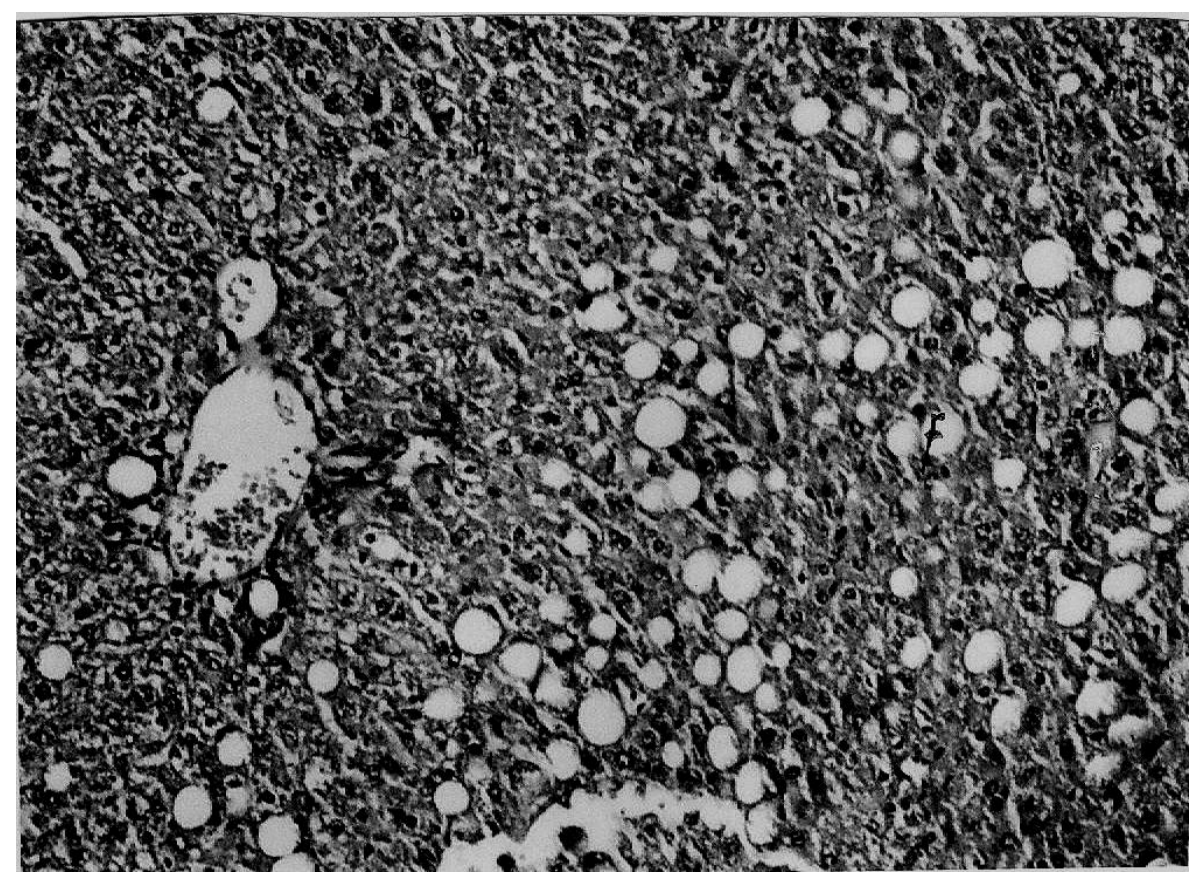

Fig 5. liver of mice administrated immunized egg yolk and inoculated (I/p) by salmonella typhimuruin showing focal area of fatty changes $(F)$ in the hepatocytes

$$
(H \times E \times 40)
$$

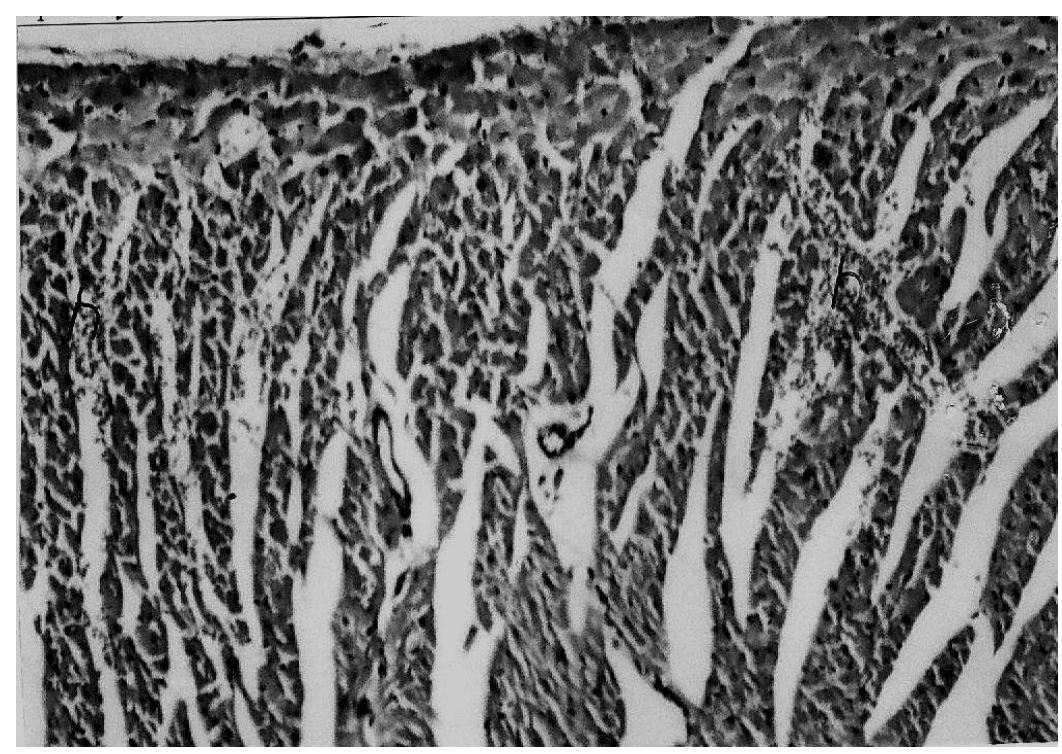

Fig 6. Heart of mice administrated immunized egg yolk and inoculated (I/p) by salmonella typhimuriun showing focal haemorrhage $(H)$ in Between myocardial bundles

$(\mathrm{H} \times E \times 40)$ 


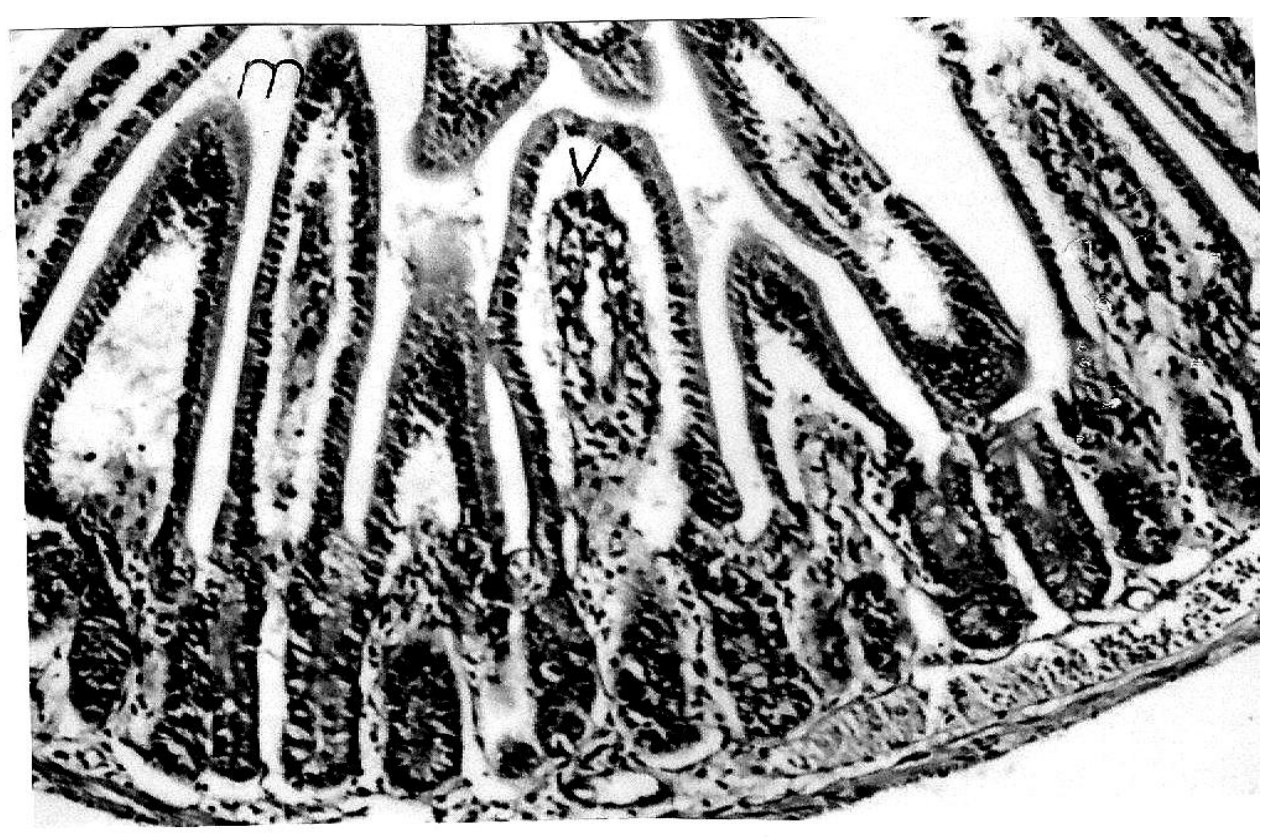

Fig 7. intestine of mice from control group showing intact normal histological structure of the villi (V) and lining mucosal layer (M). ( $H \times E \times 40$ )

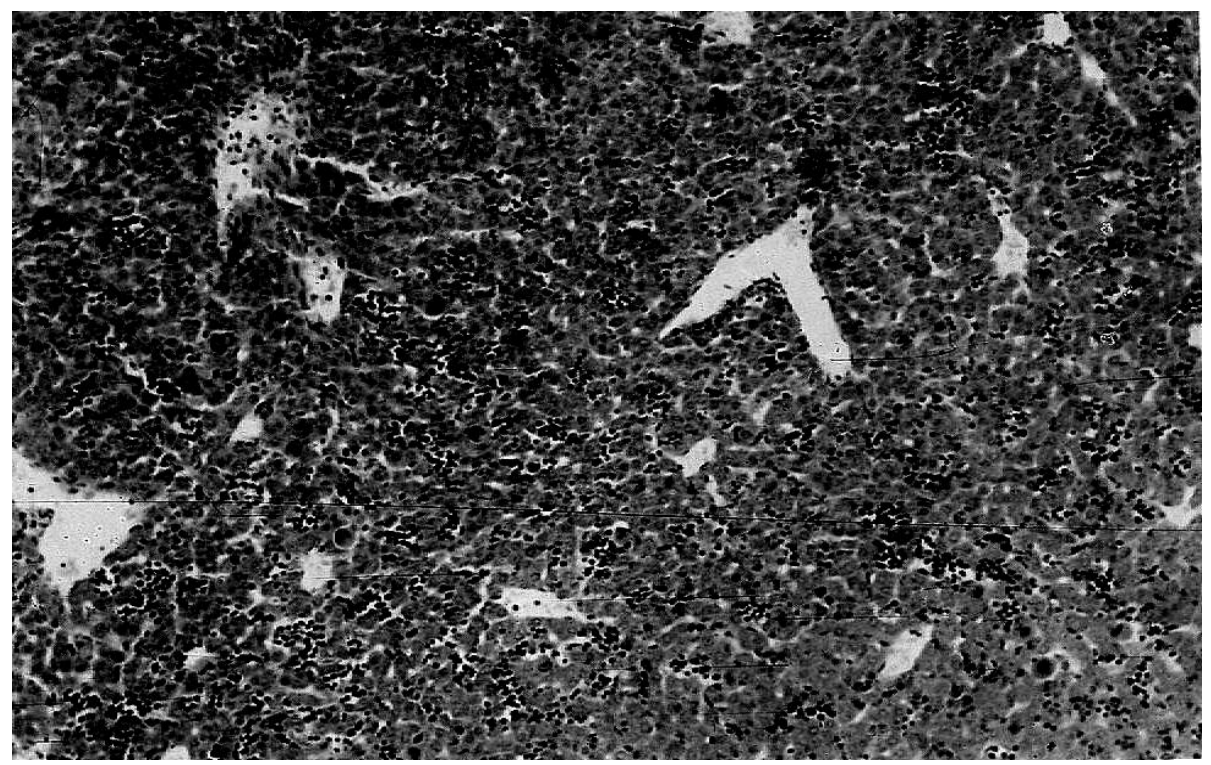

Fig 8. liver of mice from control group showing the normal histological structure. $(\mathrm{H} \times \mathrm{E} \times 40)$ 


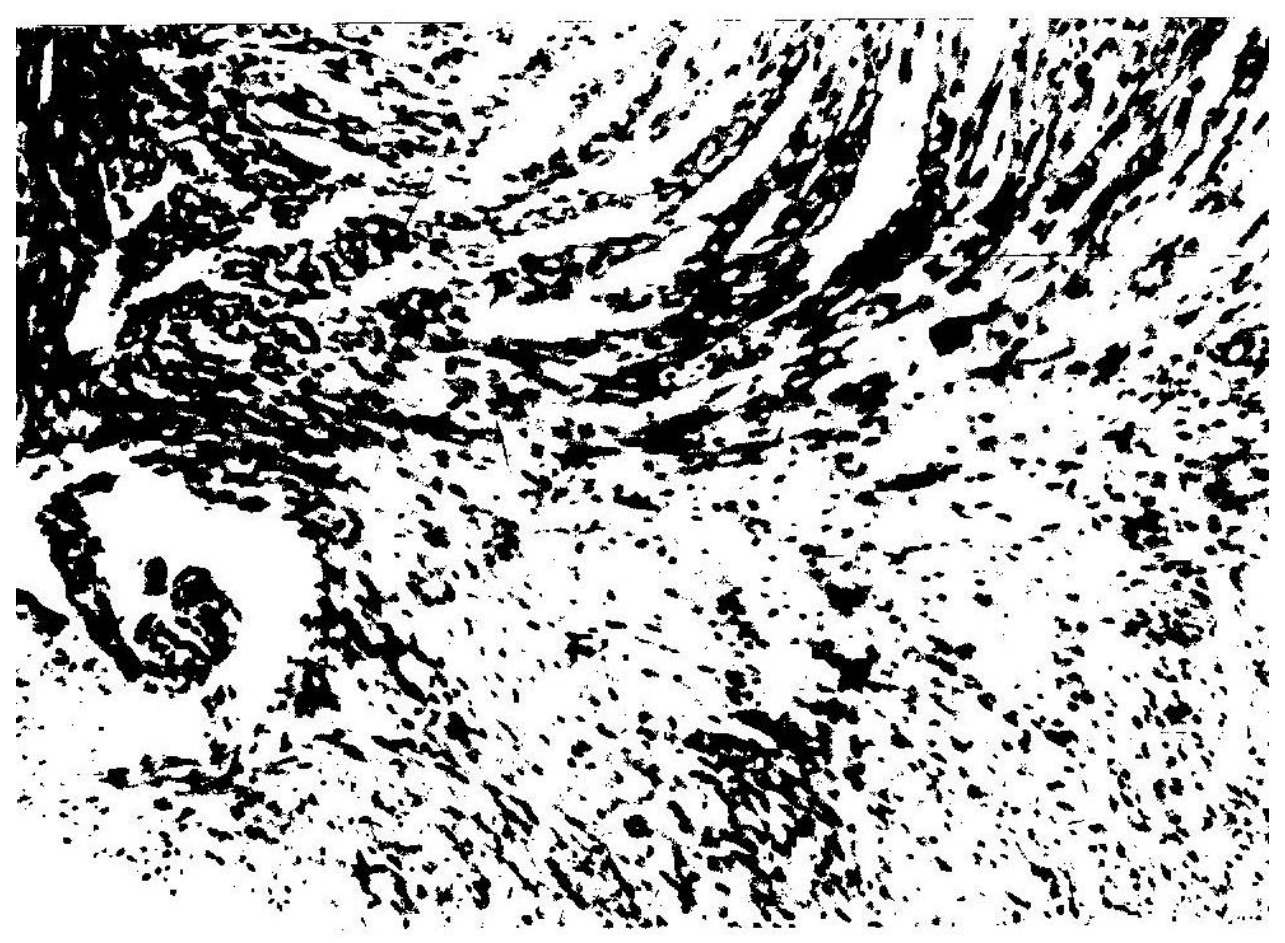

Fig 9. Heart of mice from control group showing the normal histological structure.

$(\mathrm{H} \times \mathrm{E} \times 40)$

\section{REFERENCES}

1- Bancroft, D.T., CH. Cook.. R.W. Straling and DR.Tuner 1994. Manual of Histologic technique and their diagnostic application. Churchill, livingstone, Eduburgh.

2- $\quad$ Forbes, B.A.D., F. Sohu, and K.S weissfield. 1998. Baily and scotts diagnostic Microbiology. Mosby st. Louis.

3- Germin, S.S. 2007. Protection against colibacillosis diarrhea in calves. M.V. Sc. Thesis, infectious Diseases, Fac. Vet. Med., Benha univ.

4- Hiraga, C., Y. Kodama, T. sugi jama and y.I. chikaura. 1990. Prevention of human rotavirus infection with chicken egg yolk immunoglobulins containing rota virus antibodies. J. Jap. Assoc. infect. Dis., $64: 118-123$

5- Ikemori, Y., M. Kuroki, R. C. Peralta H. yokyama and y. Kodama. 1992. Protection of neonatal calves against fatal enteric collibacillosis by administration of egg yolk powder from hens immunized with k99 piliated enterotoxigenic Escherichia coli. Amer. J. vet. Res., 53 (1) : 2005 - 2008. 
6- $\quad$ Ikemori, Y., M., Ohta, K. uneda, F.C., I catla, M., Kuraki, H. yokayand, and y. kodama 1997. Passive protection of Neonatal calves against bovine corona virus induced diarrhea by administration of egg yolk or colostrum antibody powder. Vet. Microbial., 58 (2- 4) :105 - 111.

7- Kuroki, M., Y., Ikemori, H., yokoyama, R.C., pernatta, F.C. I catla, and y. kodama, 1993. Passive protection against Bovine Rota virus induced diarrhea in Murine Model by specific immunoglobulin from chicken egg yolk.

Vet. Microbiol., 37 (1- 2) : 135 - 146.

8- Percy, D.H and SW. Barthold. 2001. Pathology of laboratory rodents and rabbits. ${ }^{2 n d}$ Ed. Iowa. State university prev Ames.

9- Pietro, M. and M. dun can, 2006. Salmonella infections, clinical immunological and Molecular aspects. ${ }^{1 s t}$ Ed. Cambridge university press.

10- Quinn P.J, D.K. Marfery, M.E., carte, W.J. Donelly and F.C. learned. 2002. Veterinary Microbiology and Microbial diseases. 1st published Blachwell, science LTD, U.K.

11- Rofaiil, S.K. 2007. Studies on some additives for reducing some enteric bacteria infection in swiss Mice. J. Egypt. Vet Med. Assoc., 67 (1) : 233 - 239

12- Rofaiil, S.K. and A.M. Daoud 2005. Study on the effect of Nigella sativa supplementation on the growth rate and experimental infection by salmonella typhimurium in swiss Mice. J. Agric. Res. 83 (2) : 947 - 955.

13- Rofaiil, S.K, A.S., Ragaa, A.E. ola and M.H. Mahmoud, 2011. Studies on some medicinal plant extracts as immune stimulant in Rats experimentally infected with salmonella typhimuruim. J. agric. Res. 89 (1) : 335 - 343

14- Svendsen, L., A., Crowley, L.H., Oster gaad, G. Stodulski, and J. H au, 1995. Development and comparison of purification strategies for chicken antibodies from egg yolk. Lab. Amim. Sci., 45 (1) : 89 - 93.

15- Sugita, K.y., S.S., sakamaka. L.R. Jineja , T. Noda, and F. Amana, 2002. Inhibition of Bacterial adhesion and Salmonella infection in BALB/C Mice by sialylolgosackarides and their derivatives from chicken egg yolk.

J. Agricul. And food chem.. So (12): 3607 - 3613

16- Yokoyama, H., R.C., peralta, R., Diaz, S., senda, y. Ikemore, and y. kodama, 1992. Passive protective effect of chicken egg yolk immunoglobulinic Escherichia coli infection in neonatal piglets. Infect. Immun., 60 (3) : 998 1007. 
تأثير القدرة الوقائية لصفار البيض ضد الإصابة بالسالمونيلا

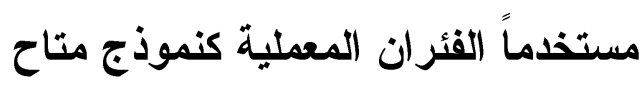

صفوت كمال روفائيل ، جرمين صبحى سعد

معهُ بحوث الأمصال واللقاحات البيطرية - مركز البحوث الزراعية - الدقى - الجيزة

أجريت هذه الدر اسة لمعرفة القدرة الوقائية لصفار البيض المأخوذ من دجاجات محصنة بلقاح

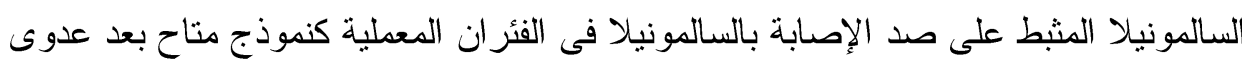

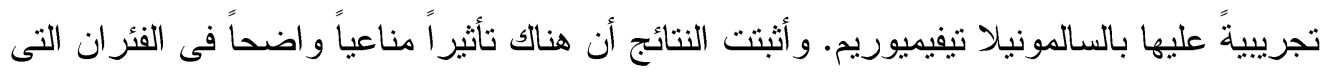

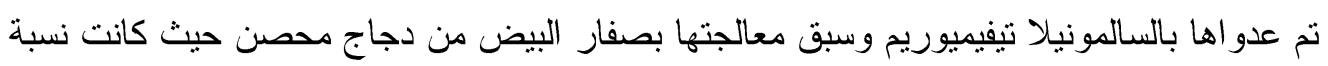

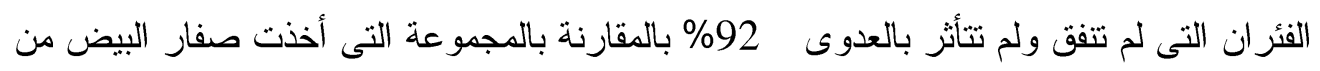

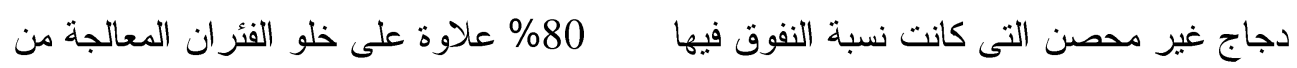
الميكروب المعدى بالفحص البكتريولوجى كما لوحظ عدم وجود آية تغيرات هستوباثولوجية في أمعاء تللك المجموعة المعالجة إلا بعض التغيرات البسيطة فى الكبد والقلب لتلك المجموعة المعالجة. بينما

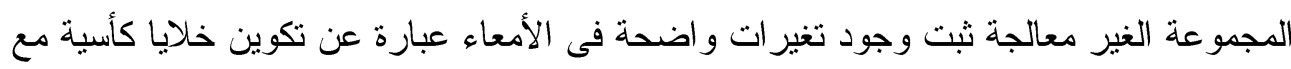

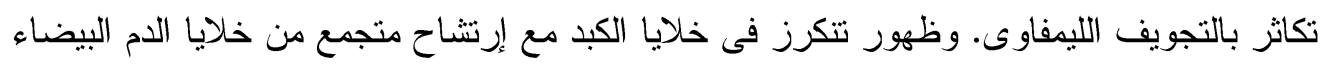

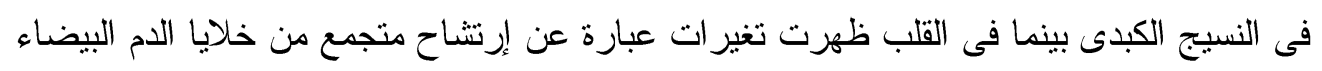
بين الأوعية المتخللة لعضلة القلب مع إحتقان.

من خلال تلك الدراسة يمكن أن يوصى بإمكانية استخدام صفار البيض المأخوذ من الدجاجات

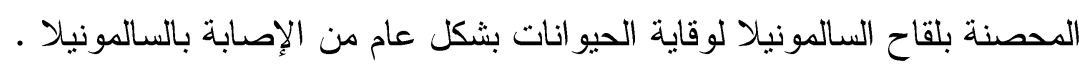

